\title{
Decomposition of high-level ozone under high humidity over Mn-Fe catalyst: The influence of iron precursors
}

\author{
Zhihua Lian, Jinzhu Ma, Hong He * \\ State Key Joint Laboratory of Environment Simulation and Pollution Control, Research Center for Eco-Environmental Sciences, Chinese Academy of Sciences, Beijing 100085, PR China
}

\section{A R T I C L E I N F O}

\section{Article history:}

Received 21 April 2014

Received in revised form 28 August 2014

Accepted 14 October 2014

Available online 23 October 2014

\section{Keywords:}

Ozone decomposition

Mn-Fe catalyst

Precursors

High-level ozone

High humidity

\begin{abstract}
A B S T R A C T
Manganese-iron mixed oxide, an efficient and stable catalyst, has been successfully used in the decomposition of ozone. The influence of different iron precursors on the catalytic decomposition activity of high-level ozone under high-humidity over manganese-iron catalysts prepared using a hydrothermal approach was studied. The catalytic performance over $\mathrm{MnFe}_{0.5} \mathrm{O}_{x}-\mathrm{Fe}\left(\mathrm{NO}_{3}\right)_{3}$ was much better than that of $\mathrm{MnFe}_{0.5} \mathrm{O}_{x}-\mathrm{FeSO}_{4}$ and $\mathrm{MnFe}_{0.5} \mathrm{O}_{X}-\mathrm{FeCl}_{3}$. From the results of characterization by $\mathrm{N}_{2}$ physical adsorption, XRD, XPS and SEM, it was concluded that the largest specific surface area, the lowest crystallinity, the most evenly distributed particle size and the most surface-active $\mathrm{Mn}^{2+}$ and $\mathrm{Mn}^{3+}$ led to the best catalytic activity for the $\mathrm{MnFe}_{0.5} \mathrm{O}_{x}-\mathrm{Fe}\left(\mathrm{NO}_{3}\right)_{3}$ catalyst.
\end{abstract}

(c) 2014 Elsevier B.V. All rights reserved.

\section{Introduction}

As a strong oxidant, ozone has been widely used in drinking water and wastewater treatment for disinfection and oxidation (e.g., taste and odor control, decolorization, and elimination of micropollutants) [1-5]. The resulting tail gas still contains some amount of ozone, which should be removed before discharge. Some modern indoor devices such as photocopiers, laser printers, and ozone disinfection machines also encounter the problem of ozone emission. Tropospheric ozone is a common pollutant that causes health problems to human beings including reduced lung function, increased frequency of respiratory symptoms, and development of asthma [6,7]. Because of its toxicity, the Occupational Safety and Health Administration (OSHA, the United States of America) has set the maximum human allowable exposure to ozone for an eight-hour period at $0.10 \mathrm{ppm}$ [8]. Chinese 'indoor air quality standards' (GB/T 18883-2002) requires that indoor ozone concentration should not exceed $0.16 \mathrm{mg} / \mathrm{m}^{3}(0.07 \mathrm{ppm})$ [9]. Thus, it is urgently necessary to develop effective methods to eliminate ozone in order to protect human health from the increasing ozone exposure in our environment.

Various methods such as dilution, liquid absorption, thermal decomposition and catalytic decomposition have been reported to control ozone emission [10-13]. Among them, catalytic decomposition is the most widely used method, due to its advantages of mild reaction conditions, high efficiency and low cost. Numerous catalysts have been investigated, including transition metal oxides [14-21], activated

\footnotetext{
* Corresponding author. Tel./fax: + 861062849123.

E-mail address: honghe@rcees.ac.cn (H. He).
}

carbon [22,23] and noble metals [24-26]. Among these catalysts, manganese oxides $\left(\mathrm{MnO}_{x}\right)$ usually show good catalytic performance in ozone decomposition. However, the catalytic activity tends to decrease with coexisting water vapor and operation time $[20,21]$.

In this study, the modification of $\mathrm{MnO}_{x}$ by adding Fe and the influence of different iron precursors on the catalytic decomposition activity of high-level ozone under high humidity over manganese-iron oxides catalysts were investigated. The $\mathrm{MnFe}_{0.5} \mathrm{O}_{x}-\mathrm{Fe}\left(\mathrm{NO}_{3}\right)_{3}$ catalyst exhibited the best catalytic activity and stability, which was related to it possessing the largest specific surface area, the lowest crystallinity, the most surface-active $\mathrm{Mn}^{2+}$ and $\mathrm{Mn}^{3+}$ and the most evenly distributed particle size.

\section{Experimental}

\subsection{Catalyst synthesis and activity test}

The Mn-Fe catalysts were synthesized by hydrothermally treating a suspension containing $\mathrm{MnSO}_{4} \cdot \mathrm{H}_{2} \mathrm{O}, \mathrm{KMnO}_{4}$ and the desired amount of Fe precursors in a Teflon-lined autoclave at $100^{\circ} \mathrm{C}$ for $24 \mathrm{~h}$. The resulting black slurry was centrifuged, washed by deionized water and dried at $100^{\circ} \mathrm{C}$ overnight, followed by calcination at $350^{\circ} \mathrm{C}$ in air for $3 \mathrm{~h}$ for characterization and evaluation of catalytic performance. $\mathrm{MnO}_{x}$ was also prepared by the same process. $\mathrm{Mn}-\mathrm{Fe}$ catalysts with different ratios of $\mathrm{Fe} / \mathrm{Mn}$ were prepared using $\mathrm{Fe}\left(\mathrm{NO}_{3}\right)_{3}$ as $\mathrm{Fe}$ precursor. The Fe precursors of $\mathrm{MnFe}_{0.5} \mathrm{O}_{x}-\mathrm{FeCl}_{3}$ and $\mathrm{MnFe}_{0.5} \mathrm{O}_{x}-\mathrm{FeSO}_{4}$ catalysts were $\mathrm{FeCl}_{3}$ and $\mathrm{FeSO}_{4}$, respectively.

Ozone decomposition was studied in a flow reactor at ambient temperature $\left(25^{\circ} \mathrm{C}\right)$. The reaction conditions were controlled as follows: 
ozone concentration $21.43 \mathrm{~g} / \mathrm{m}^{3}$ (10,000 ppm), air balance, gas flow $40 \mathrm{~mL} / \mathrm{min}$, catalyst $0.2 \mathrm{~g}, 40 \%$ or $90 \%$ relative humidity. Ozone concentration was recorded with an ozone analyzer (2B Technology, US). Ozone conversion was calculated as follows:

$\mathrm{O}_{3}$ conversion $=\frac{\mathrm{C}_{\text {in }}-\mathrm{C}_{\text {out }}}{\mathrm{C}_{\text {in }}}$

\subsection{Characterization of catalysts}

The surface area and pore characterization of the catalysts were obtained from $\mathrm{N}_{2}$ adsorption/desorption analysis at $-196{ }^{\circ} \mathrm{C}$ using a Quantachrome Quadrasorb SI-MP. Prior to the $\mathrm{N}_{2}$ physisorption, the catalysts were degassed at $300{ }^{\circ} \mathrm{C}$ for $5 \mathrm{~h}$. Surface areas were determined using the BET equation in the $0.05-0.35$ partial pressure range. Pore volumes and average pore diameters were determined by the BarrettJoyner-Halenda $(\mathrm{BJH})$ method from the desorption branches of the isotherms.

Powder X-ray diffraction (XRD) measurements of the catalysts were carried out on a computerized PANalytical X'Pert Pro diffractometer with $\mathrm{Cu} \mathrm{K \alpha}(\lambda=0.15406 \mathrm{~nm})$ radiation. The data of $2 \theta$ from 10 to $90^{\circ}$ were collected at $8^{\circ} / \mathrm{min}$ with step size of $0.07^{\circ}$.

$\mathrm{X}$-ray photoelectron spectroscopy (XPS) results of the catalysts were recorded on a scanning X-ray microprobe (Axis Ultra, Kratos Analytical Ltd.) using $\mathrm{Al} \mathrm{K} \alpha$ radiation ( $1486.7 \mathrm{eV}$ ).

The surface morphology of the samples was studied using a fieldemission scanning electron microscope (FESEM, Hitachi, SU-8020). The accelerating voltage was $3.0 \mathrm{kV}$.

\section{Results and discussion}

\subsection{Catalytic performance}

Fig. 1 shows ozone conversion as a function of time over Mn-Fe catalysts. The initial catalytic activity over all the catalysts was $100 \%$ at $25{ }^{\circ} \mathrm{C}$. Ozone conversion over the $\mathrm{MnO}_{x}$ catalyst decreased quickly and only $40 \%$ conversion was obtained after 30 min under $90 \%$ relative humidity. The addition of Fe enhanced catalytic activity remarkably. With the increase of Fe content, catalytic activity over Mn-Fe catalysts increased. $\mathrm{MnFe}_{0.5} \mathrm{O}_{x}$ exhibited the best catalytic performance and maintained as high as $90 \%$ ozone conversion after an 8 h test. Any further increase in Fe content resulted in a decline in activity.

Different precursors could affect structural properties of catalysts such as dispersion, crystallinity and morphology $[27,28]$ and then influence catalytic performance. Thus the influence of Fe precursors on

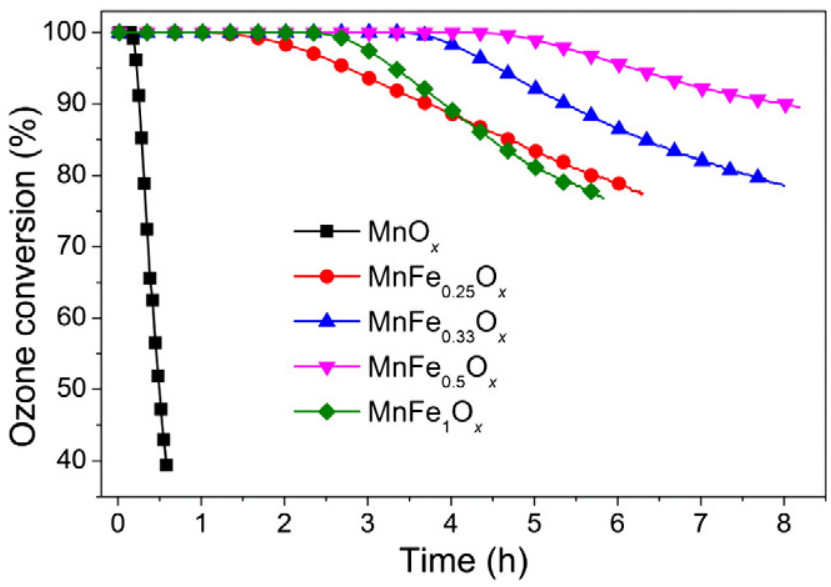

Fig. 1. Ozone conversion as a function of time over Mn-Fe catalysts (ozone initial concentration $21.43 \mathrm{~g} / \mathrm{m}^{3}$, temperature $25{ }^{\circ} \mathrm{C}$, weight space velocity $12 \mathrm{~L} /(\mathrm{g} \cdot \mathrm{h}), \mathrm{RH}>90 \%$ ).

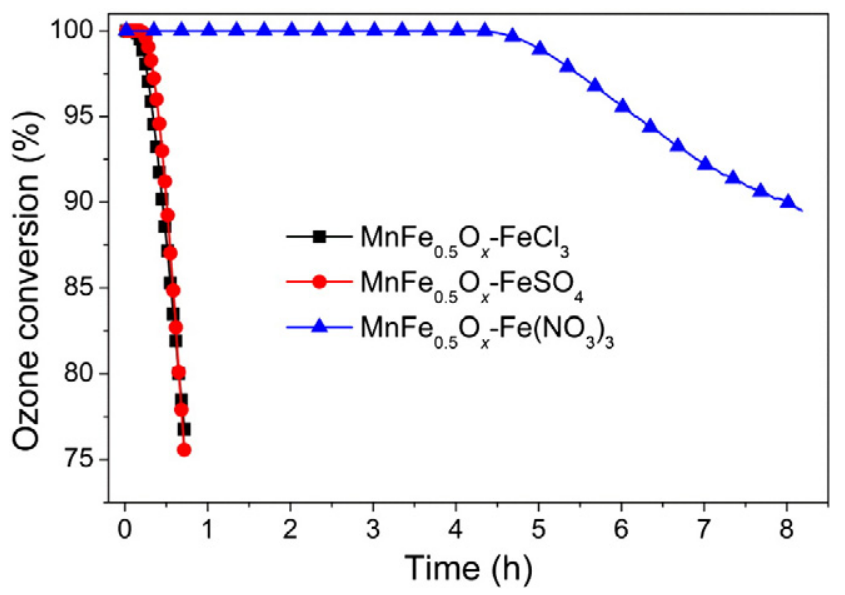

Fig. 2. Ozone conversion as a function of time over $\mathrm{MnFe}_{0.5} \mathrm{O}_{x}$ catalysts of different precursors (ozone initial concentration $21.43 \mathrm{~g} / \mathrm{m}^{3}$, temperature $25^{\circ} \mathrm{C}$, weight space velocity $12 \mathrm{~L} /(\mathrm{g} \cdot \mathrm{h}), \mathrm{RH}>90 \%)$

catalytic ozone conversion was investigated and the results are shown in Fig. 2. $\mathrm{MnFe}_{0.5} \mathrm{O}_{x}-\mathrm{FeSO}_{4}$ and $\mathrm{MnFe}_{0.5} \mathrm{O}_{x}-\mathrm{FeCl}_{3}$ catalysts exhibited similar catalytic performance. Ozone conversion decreased quickly to $80 \%$ after a 40 min test. However, the $\mathrm{MnFe}_{0.5} \mathrm{O}_{x}-\mathrm{Fe}\left(\mathrm{NO}_{3}\right)_{3}$ catalyst showed the best catalytic performance and still maintained $90 \%$ ozone conversion after an $8 \mathrm{~h}$ test. In the following sections, we will investigate the influence of precursors on structure, morphology and surface properties of $\mathrm{MnFe}_{0.5} \mathrm{O}_{x}$ catalysts using various characterization methods.

\subsection{Catalyst characterization}

$\mathrm{N}_{2}$ adsorption-desorption isotherms and the pore size distributions of $\mathrm{MnFe}_{0.5} \mathrm{O}_{x}$ and $\mathrm{MnO}_{x}$ catalysts are shown in Fig. S1 and Fig. S2. The $\mathrm{MnFe}_{0.5} \mathrm{O}_{x}-\mathrm{Fe}\left(\mathrm{NO}_{3}\right)_{3}$ catalyst showed type IV isotherms, which are typical for mesoporous materials (2-50 $\mathrm{nm}$ pore diameter). The addition of Fe to $\mathrm{MnO}_{x}$ decreased the pore diameter.

Calculated from the isotherms, the surface area and pore characterization of $\mathrm{MnFe}_{0.5} \mathrm{O}_{x}$ and $\mathrm{MnO}_{x}$ catalysts are shown in Table $1 . \mathrm{MnO}_{x}$ exhibited the smallest specific surface area and the largest average pore diameter. The addition of Fe led to the increase of surface area and the decrease of pore diameter. Furthermore, the specific surface area and pore volume of the $\mathrm{MnFe}_{0.5} \mathrm{O}_{x}-\mathrm{Fe}\left(\mathrm{NO}_{3}\right)_{3}$ catalyst were clearly larger than that of $\mathrm{MnFe}_{0.5} \mathrm{O}_{x}-\mathrm{FeSO}_{4}$ and $\mathrm{MnFe}_{0.5} \mathrm{O}_{x}-\mathrm{FeCl}_{3}$ catalysts. The large specific surface area and pore volume of the $\mathrm{MnFe}_{0.5} \mathrm{O}_{x}-\mathrm{Fe}\left(\mathrm{NO}_{3}\right)_{3}$ catalyst are beneficial for ozone decomposition, as shown in Fig. 2.

XRD patterns of $\mathrm{MnFe}_{0.5} \mathrm{O}_{x}$ and $\mathrm{MnO}_{x}$ catalysts are shown in Fig. 3. The $\mathrm{MnO}_{x}$ catalyst displayed well-defined diffraction peaks attributed to $\alpha-\mathrm{MnO}_{2}$ (JCPDS 44-0141). The diffraction peaks of $\mathrm{MnFe}_{0.5} \mathrm{O}_{x}-\mathrm{FeSO}_{4}$ and $\mathrm{MnFe}_{0.5} \mathrm{O}_{x}-\mathrm{FeCl}_{3}$ catalysts were also consistent with the $\alpha-\mathrm{MnO}_{2}$ structure, but the intensity was notably decreased compared with that of $\mathrm{MnO}_{x}$ catalyst, indicating that the addition of Fe led to a decrease in $\mathrm{MnO}_{2}$ crystallinity. The diffraction line of the $\mathrm{MnFe}_{0.5} \mathrm{O}_{x}-\mathrm{Fe}\left(\mathrm{NO}_{3}\right)_{3}$ catalyst around $37.5^{\circ}$ was shifted slightly to the lower angle region (from $37.49^{\circ}$ to $36.86^{\circ}$ ) compared to that of $\mathrm{MnO}_{x}$. This may be due to the existence of a Mn-Fe solid solution oxide.

Table 1

The surface area and pore characterization of $\mathrm{MnFe}_{0.5} \mathrm{O}_{x}$ and $\mathrm{MnO}_{x}$ catalysts.

\begin{tabular}{llll}
\hline Catalysts & $\begin{array}{l}\text { Specific surface area } \\
\left(\mathrm{m}^{2} / \mathrm{g}\right)\end{array}$ & $\begin{array}{l}\text { Pore volume } \\
\left(\mathrm{cm}^{3} / \mathrm{g}\right)\end{array}$ & $\begin{array}{l}\text { Pore diameter } \\
(\mathrm{nm})\end{array}$ \\
\hline $\mathrm{MnO}_{x}$ & 71.7 & 0.612 & 34.2 \\
$\mathrm{MnFe}_{0.5} \mathrm{O}_{x}-\mathrm{FeCl}_{3}$ & 172 & 0.285 & 6.60 \\
$\mathrm{MnFe}_{0.5} \mathrm{O}_{x}-\mathrm{FeSO}_{4}$ & 168 & 0.238 & 4.90 \\
$\mathrm{MnFe}_{0.5} \mathrm{O}_{x}-\mathrm{Fe}\left(\mathrm{NO}_{3}\right)_{3}$ & 262 & 0.573 & 5.63 \\
\hline
\end{tabular}




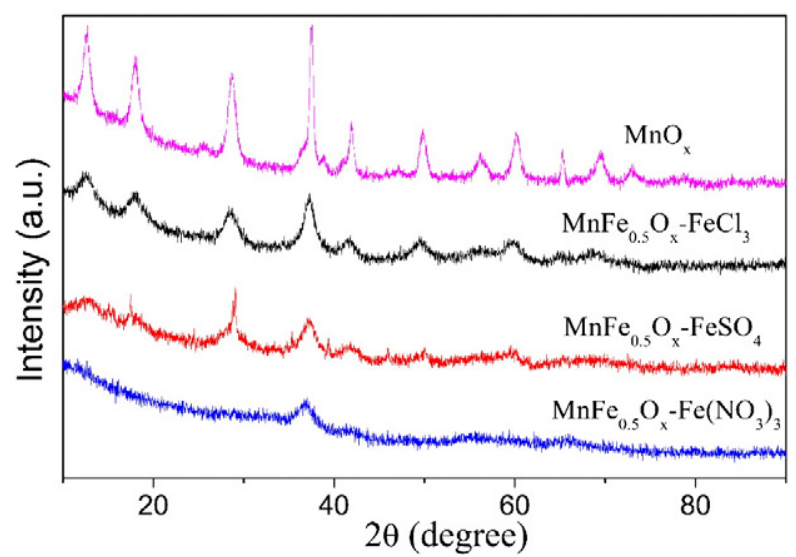

Fig. 3. XRD patterns of $\mathrm{MnFe}_{0.5} \mathrm{O}_{x}$ and $\mathrm{MnO}_{x}$ catalysts.

Table 2

Surface and bulk atomic concentration on $\mathrm{MnFe}_{0.5} \mathrm{O}_{x}$ catalysts.

\begin{tabular}{|c|c|c|c|c|c|c|c|}
\hline \multirow[t]{2}{*}{ Catalysts } & \multicolumn{5}{|c|}{ Surface atomic concentration (\%) } & \multirow{2}{*}{$\begin{array}{l}\mathrm{Fe} / \mathrm{Mn} \\
\text { (surface) }\end{array}$} & \multirow{2}{*}{$\begin{array}{l}\mathrm{Fe} / \mathrm{Mn}^{\mathrm{a}} \\
\text { (bulk) }\end{array}$} \\
\hline & $\mathrm{Mn}$ & $\mathrm{Fe}$ & 0 & $\mathrm{Cl}$ & $\mathrm{S}$ & & \\
\hline $\mathrm{MnFe}_{0.5} \mathrm{O}_{x}-\mathrm{FeCl}_{3}$ & 28.07 & 9.31 & 60.62 & 0.79 & 1.22 & 0.33 & 0.23 \\
\hline $\mathrm{MnFe}_{0.5} \mathrm{O}_{x}-\mathrm{FeSO}_{4}$ & 25.24 & 10.99 & 61.12 & 0.74 & 1.91 & 0.44 & 0.37 \\
\hline $\mathrm{MnFe}_{0.5} \mathrm{O}_{x}-\mathrm{Fe}\left(\mathrm{NO}_{3}\right)_{3}$ & 30.04 & 8.25 & 59.47 & 0.79 & 1.44 & 0.28 & 0.24 \\
\hline
\end{tabular}

a Derived from ICP-OES results.

However, compared to other catalysts, the diffraction peaks of $\mathrm{MnFe}_{0.5} \mathrm{O}_{x}-\mathrm{Fe}\left(\mathrm{NO}_{3}\right)_{3}$ weakened significantly, indicating that the catalyst was nearly amorphous. Furthermore, no extra peaks attributed to iron species were detected, suggesting that iron species were highly dispersed or were amorphous in these samples. The low crystallinity over the $\mathrm{MnFe}_{0.5} \mathrm{O}_{x}-\mathrm{Fe}\left(\mathrm{NO}_{3}\right)_{3}$ catalyst indicated more defects and possibly enhanced the surface area, which could favor the ozone decomposition.

XPS can be used to investigate the surface composition and surface elemental valence on $\mathrm{MnFe}_{0.5} \mathrm{O}_{x}$ catalysts of different precursors. The surface atomic concentrations of $\mathrm{Mn}, \mathrm{Fe}$, and $\mathrm{O}$ on $\mathrm{MnFe}_{0.5} \mathrm{O}_{x}$ catalysts are shown in Table 2. Not only the surface Fe/Mn molar ratios on the three catalysts but also the Fe/Mn molar ratios in the bulk derived from ICP-OES were lower than the molar ratio of the raw materials. This indicated that Fe was not fully used in the process of hydrothermal synthesis. The $\mathrm{MnFe}_{0.5} \mathrm{O}_{x}-\mathrm{Fe}\left(\mathrm{NO}_{3}\right)_{3}$ catalyst showed a higher surface $\mathrm{Mn}$ concentration and lower surface Fe/Mn molar ratio than other catalysts. There was almost no difference in the contents of $\mathrm{S}$ and $\mathrm{Cl}$ in the $\mathrm{MnFe}_{0.5} \mathrm{O}_{x}$ catalysts prepared from different precursors.

XPS of Mn 2p, Fe 2p and O 1s is shown in Fig. S3. $\mathrm{MnFe}_{0.5} \mathrm{O}_{x}$ catalysts of three different precursors including $\mathrm{FeCl}_{3}, \mathrm{FeSO}_{4}$, and $\mathrm{Fe}\left(\mathrm{NO}_{3}\right)_{3}$ showed similar Fe 2p spectra. The XPS of $\mathrm{O}$ 1s was deconvoluted into three peaks, including the lattice oxygen (denoted as $\mathrm{O}_{\beta}$ ), the surface adsorbed oxygen (denoted as $\mathrm{O}_{\alpha}$ ) and chemisorbed water (denoted as $\mathrm{O}_{\alpha}{ }^{\prime}$ ). The XPS of Mn 2p was also deconvoluted into three peaks, and Table 3 presents the surface $\mathrm{Mn}$ valence distribution on the $\mathrm{MnFe}_{0.5} \mathrm{O}_{x}$ catalysts prepared from different precursors. Surface $\mathrm{Mn}$ on $\mathrm{MnFe}_{0.5} \mathrm{O}_{x}-\mathrm{FeSO}_{4}$ and $\mathrm{MnFe}_{0.5} \mathrm{O}_{x}-\mathrm{FeCl}_{3}$ catalysts existed mainly in the form of $\mathrm{Mn}^{4+}$. However, the most abundant $\mathrm{Mn}^{2+}$ and $\mathrm{Mn}^{3+}$ existed on the surface of the
$\mathrm{MnFe}_{0.5} \mathrm{O}_{x}-\mathrm{Fe}\left(\mathrm{NO}_{3}\right)_{3}$ catalyst, which could be the reason for its superior catalytic performance, as discussed below.

Catalyst morphology was investigated by FESEM and the results are shown in Fig. 4. The $\mathrm{MnO}_{x}$ catalyst showed a nanowire structure. The addition of $\mathrm{Fe}$ to $\mathrm{MnO}_{x}$ altered the morphology significantly. Besides, the morphologies of $\mathrm{MnFe}_{0.5} \mathrm{O}_{x}$ catalysts were influenced by the iron precursors. $\mathrm{MnFe}_{0.5} \mathrm{O}_{x}-\mathrm{FeSO}_{4}$ and $\mathrm{MnFe}_{0.5} \mathrm{O}_{x}-\mathrm{FeCl}_{3}$ catalysts exhibited irregular shape and non-uniform particle size distribution, while the $\mathrm{MnFe}_{0.5} \mathrm{O}_{x}-\mathrm{Fe}\left(\mathrm{NO}_{3}\right)_{3}$ catalyst exhibited more regular spherical particles, smaller particle size and more uniform particle size distribution.

The $\mathrm{MnFe}_{0.5} \mathrm{O}_{x}$ catalysts showed different specific surface areas, crystallinity, morphology and surface Mn valence distribution with the different iron precursors. In the hydrothermal process, slight differences in $\mathrm{pH}$ in the solution could lead to distinct morphology and structure variations $[29,30]$. The experimental temperature, precursor, surfactants and $\mathrm{pH}$ control the crystallization of metal oxides with controlled sizes and shapes [31]. Manganese precursors could affect the crystal phase, pore structure and Mn dispersion and then influence oxidative activity [32]. In light of these previous reports, we suggested that the different iron precursors including $\mathrm{FeCl}_{3}, \mathrm{FeSO}_{4}$ and $\mathrm{Fe}\left(\mathrm{NO}_{3}\right)_{3}$ could lead to different $\mathrm{pH}$ and ionic strength in the solution and then affect the hydrolysis rate and nucleation rate of Mn and Fe. Finally, it could result in different structure, morphology, surface composition and surface elemental valence for the catalysts. The $\mathrm{MnO}_{x}$ catalyst showed different structural properties from the Mn-Fe oxide catalysts. The doped metal oxide influenced the structure and morphology of the catalyst [33]. The addition of Fe to $\mathrm{MnO}_{x}$ affected the nucleation process and then decreased the crystallinity of the catalysts. The highest specific surface area for $\mathrm{MnFe}_{0.5} \mathrm{O}_{x}-\mathrm{Fe}\left(\mathrm{NO}_{3}\right)_{3}$ may be due to it having the lowest crystallinity. Therefore, the $\mathrm{MnFe}_{0.5} \mathrm{O}_{x}$ catalyst derived from $\mathrm{Fe}\left(\mathrm{NO}_{3}\right)_{3}$ showed the highest specific surface area, the lowest crystallinity, the most evenly distributed particle size and the most surface-active $\mathrm{Mn}^{2+}$ and $\mathrm{Mn}^{3+}$.

\subsection{Stability test}

Water vapor has a severe influence on catalytic performance in ozone decomposition. The stability of the $\mathrm{MnFe}_{0.5} \mathrm{O}_{x}-\mathrm{Fe}\left(\mathrm{NO}_{3}\right)_{3}$ catalyst was investigated under low humidity and the result is shown in Fig. 5. The ozone conversion was still maintained at $100 \%$ after a 66 h test under $40 \%$ relative humidity ( $\mathrm{RH})$. The catalytic activity and stability under $90 \% \mathrm{RH}$ were lower than for $40 \% \mathrm{RH}$, which could be due to the formation of a liquid film from accumulation of water molecules, preventing ozone from contacting surface active sites and thus decreasing catalytic activity [34]. The $\mathrm{MnFe}_{0.5} \mathrm{O}_{x}-\mathrm{Fe}\left(\mathrm{NO}_{3}\right)_{3}$ catalyst exhibited excellent catalytic stability and is promising for practical application.

\subsection{Reaction mechanism}

According to the literature [16,35], ozone decomposition follows the scheme:

$$
\begin{aligned}
& \mathrm{O}_{3}+\left[\mathrm{M}^{\mathrm{n}+}\right] \rightarrow \mathrm{O}_{2}+\mathrm{O}^{-}\left[\mathrm{M}^{\mathrm{n}+1}\right] \\
& \mathrm{O}_{3}+\mathrm{O}^{-}\left[\mathrm{M}^{\mathrm{n}+1}\right] \rightarrow 2 \mathrm{O}_{2}+\left[\mathrm{M}^{\mathrm{n}+}\right] .
\end{aligned}
$$

Table 3

\begin{tabular}{|c|c|c|c|}
\hline Catalysts & $\begin{array}{l}\mathrm{Mn}^{2+} /\left(\mathrm{Mn}^{2+}+\mathrm{Mn}^{3+}+\mathrm{Mn}^{4+}\right) \\
(\%)\end{array}$ & $\begin{array}{l}\mathrm{Mn}^{3+} /\left(\mathrm{Mn}^{2+}+\mathrm{Mn}^{3+}+\mathrm{Mn}^{4+}\right) \\
(\%)\end{array}$ & $\begin{array}{l}\mathrm{Mn}^{4+} /\left(\mathrm{Mn}^{2+}+\mathrm{Mn}^{3+}+\mathrm{Mn}^{4+}\right) \\
(\%)\end{array}$ \\
\hline $\mathrm{MnFe}_{0.5} \mathrm{O}_{x}-\mathrm{FeCl}_{3}$ & 9.17 & 25.52 & 65.31 \\
\hline $\mathrm{MnFe}_{0.5} \mathrm{O}_{x}-\mathrm{FeSO}_{4}$ & 10.50 & 29.25 & 60.25 \\
\hline $\mathrm{MnFe}_{0.5} \mathrm{O}_{x}-\mathrm{Fe}\left(\mathrm{NO}_{3}\right)_{3}$ & 16.37 & 37.66 & 45.97 \\
\hline
\end{tabular}

XPS results of surface $\mathrm{Mn}$ species on $\mathrm{MnFe}_{0.5} \mathrm{O}_{x}$ catalysts surface. 


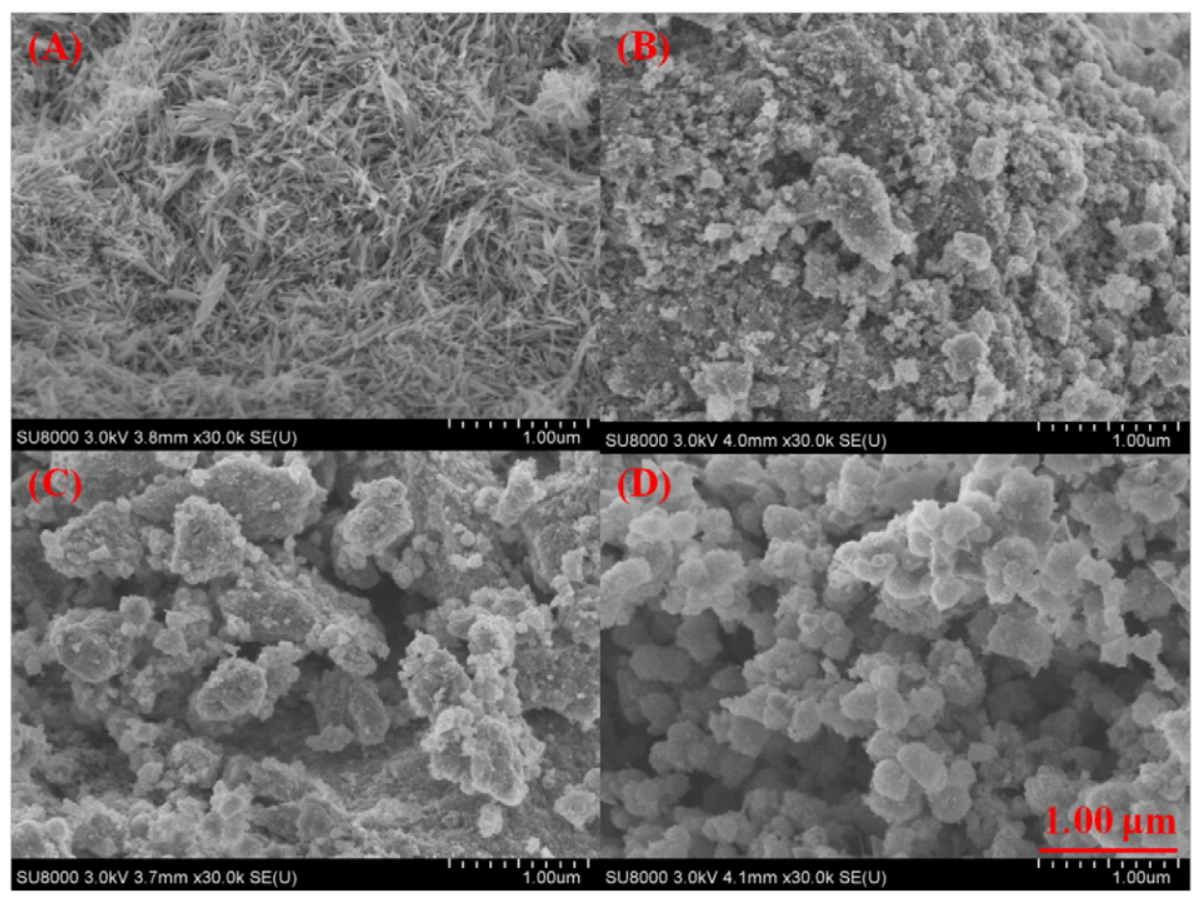

Fig. 4. FESEM images of $\mathrm{MnO}_{x}$ catalyst (A), $\mathrm{MnFe}_{0.5} \mathrm{O}_{x}-\mathrm{FeCl}_{3}$ catalyst (B), $\mathrm{MnFe}_{0.5} \mathrm{O}_{x}-\mathrm{FeSO}_{4}$ catalyst (C), $\mathrm{MnFe}_{0.5} \mathrm{O}_{x}-\mathrm{Fe}\left(\mathrm{NO}_{3}\right)_{3}$ catalyst (D).

Transition metal oxides with several oxidation states could potentially show good catalytic performance in ozone decomposition. In the case of Mn-Fe mixed oxide catalysts, we have redox couples including $\mathrm{Mn}^{2+}-\mathrm{Mn}^{3+}-\mathrm{Mn}^{4+}$ and $\mathrm{Fe}^{2+}-\mathrm{Fe}^{3+}$. These couples could be represented by the following model for the reaction mechanism:

$$
\begin{aligned}
& \mathrm{O}_{3}+\left[\mathrm{Mn}^{3+}\right] \rightarrow \mathrm{O}_{2}+\mathrm{O}^{-}\left[\mathrm{Mn}^{4+}\right] \\
& \mathrm{O}_{3}+\mathrm{O}^{-}\left[\mathrm{Mn}^{4+}\right] \rightarrow 2 \mathrm{O}_{2}+\left[\mathrm{Mn}^{3+}\right] \\
& \mathrm{O}_{3}+\left[\mathrm{Mn}^{2+}\right] \rightarrow \mathrm{O}_{2}+\mathrm{O}^{-}\left[\mathrm{Mn}^{3+}\right] \\
& \mathrm{O}_{3}+\mathrm{O}^{-}\left[\mathrm{Mn}^{3+}\right] \rightarrow 2 \mathrm{O}_{2}+\left[\mathrm{Mn}^{2+}\right]
\end{aligned}
$$

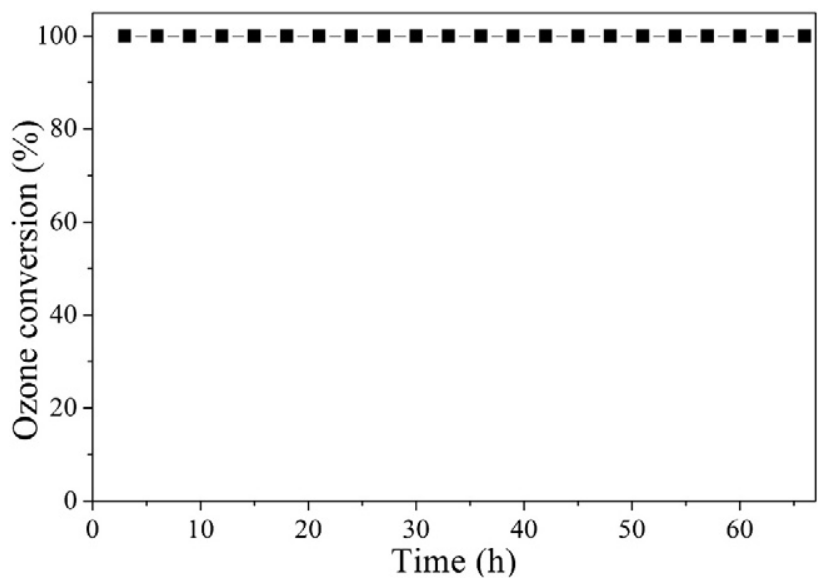

Fig. 5. Stability test result of $\mathrm{MnFe}_{0.5} \mathrm{O}_{x}-\mathrm{Fe}\left(\mathrm{NO}_{3}\right)_{3}$ catalyst (ozone initial concentration $21.43 \mathrm{~g} / \mathrm{m}^{3}$, temperature $25{ }^{\circ} \mathrm{C}$, weight space velocity $12 \mathrm{~L} /(\mathrm{g} \cdot \mathrm{h}), \mathrm{RH}=40 \%$ ).

$$
\mathrm{O}_{3}+\left[\mathrm{Mn}^{2+}\right] \rightarrow \mathrm{O}_{2}+\mathrm{O}^{2-}\left[\mathrm{Mn}^{4+}\right]
$$

$\mathrm{O}_{3}+\mathrm{O}^{2-}\left[\mathrm{Mn}^{4+}\right] \rightarrow 2 \mathrm{O}_{2}+\left[\mathrm{Mn}^{2+}\right]$

$\mathrm{O}_{3}+\left[\mathrm{Fe}^{2+}\right] \rightarrow \mathrm{O}_{2}+\mathrm{O}^{-}\left[\mathrm{Fe}^{3+}\right]$

$\mathrm{O}_{3}+\mathrm{O}^{-}\left[\mathrm{Fe}^{3+}\right] \rightarrow 2 \mathrm{O}_{2}+\left[\mathrm{Fe}^{2+}\right]$

There are two redox couples, $\mathrm{Mn}^{2+}-\mathrm{Mn}^{3+}-\mathrm{Mn}^{4+}$ and $\mathrm{Fe}^{2+}-\mathrm{Fe}^{3+}$, in $\mathrm{Mn}-\mathrm{Fe}$ mixed oxides, while only $\mathrm{Mn}^{2+}-\mathrm{Mn}^{3+}-\mathrm{Mn}^{4+}$ is present in the $\mathrm{MnO}_{x}$ catalyst. Thus Mn-Fe oxide catalysts showed higher catalytic activity than the $\mathrm{MnO}_{x}$ catalyst. Abundant $\mathrm{Mn}^{2+}$ and $\mathrm{Mn}^{3+}$ existed on the surface of the $\mathrm{MnFe}_{0.5} \mathrm{O}_{x}-\mathrm{Fe}\left(\mathrm{NO}_{3}\right)_{3}$ catalyst (Table 3 ), which could favor the redox process. Therefore, the $\mathrm{MnFe}_{0.5} \mathrm{O}_{x}-\mathrm{Fe}\left(\mathrm{NO}_{3}\right)_{3}$ catalyst showed better catalytic performance than $\mathrm{MnFe}_{0.5} \mathrm{O}_{x}-\mathrm{FeCl}_{3}$ and $\mathrm{MnFe}_{0.5} \mathrm{O}_{x}-\mathrm{FeSO}_{4}$ catalysts, in which surface Mn mainly existed in the form of $\mathrm{Mn}^{4+}$.

\section{Conclusions}

Mn-Fe mixed oxide catalysts prepared by a hydrothermal method showed higher catalytic ozone decomposition activity than $\mathrm{MnO}_{x}$ catalyst. Among catalysts with different $\mathrm{Fe} / \mathrm{Mn}$ ratios, $\mathrm{MnFe}_{0.5} \mathrm{O}_{x}$ exhibited the best catalytic performance. $\mathrm{MnFe}_{0.5} \mathrm{O}_{x}$ using $\mathrm{Fe}\left(\mathrm{NO}_{3}\right)_{3}$ as Fe precursor displayed higher ozone conversion and better stability than catalysts using $\mathrm{FeCl}_{3}$ or $\mathrm{FeSO}_{4}$ as Fe precursor. The ozone conversion over the $\mathrm{MnFe}_{0.5} \mathrm{O}_{x}-\mathrm{Fe}\left(\mathrm{NO}_{3}\right)_{3}$ catalyst was still maintained at $100 \%$ after a $66 \mathrm{~h}$ test under the reaction condition of $21.43 \mathrm{~g} / \mathrm{m}^{3}$ ozone initial concentration, $25{ }^{\circ} \mathrm{C}, 12 \mathrm{~L} /(\mathrm{g} \cdot \mathrm{h}) \mathrm{SV}$ and $40 \%$ relative humidity. The catalyst holds great promise for industrial application. The largest specific surface area, the lowest crystallinity, the most evenly distributed particle size and the most surface-active $\mathrm{Mn}^{2+}$ and $\mathrm{Mn}^{3+}$ were all responsible for the best catalytic activity for the $\mathrm{MnFe}_{0.5} \mathrm{O}_{x}-\mathrm{Fe}\left(\mathrm{NO}_{3}\right)_{3}$ catalyst. 


\section{Acknowledgments}

This work was supported by the Strategic Priority Research Program of the Chinese Academy of Sciences (XDB05050600).

\section{Appendix A. Supplementary data}

Supplementary data to this article can be found online at http://dx. doi.org/10.1016/j.catcom.2014.10.005 These data include MOL files and InChiKeys of the most important compounds described in this article.

\section{References}

[1] V. Yargeau, C. Leclair, Ozone Sci. Eng. 30 (2008) 175-188.

[2] K. Ikehata, N. Jodeiri Naghashkar, M. Gamal El-Din, Ozone Sci. Eng. 28 (2006) 353-414.

[3] K. Ikehata, M. Gamal El-Din, Ozone Sci. Eng. 27 (2005) 173-202.

[4] K. Ikehata, M. Gamal El-Din, Ozone Sci. Eng. 27 (2005) 83-114.

[5] T.E. Agustina, H.M. Ang, V.K. Vareek, J. Photochem. Photobiol. C 6 (2005) 264-273.

[6] U. Roland, F. Holzer, E.D. Kopinke, Appl. Catal. B Environ. 58 (2005) 217-226.

[7] C.J. Weschler, Environ. Health Perspect. 114 (2006) 1489-1496.

[8] C. Heisig, W.M. Zhang, S.T. Oyama, Appl. Catal. B Environ. 14 (1997) 117-129.

[9] Q. Yu, H. Pan, M. Zhao, Z. Liu, J. Wang, Y. Chen, M. Gong, J. Hazard. Mater. 172 (2009) 631-634.

[10] R.G. Rice, A. Netzer, Ann. Arbor. Sci. Publ. 1 (1982) 341-378.

[11] T.L. Rakitskaya, E.K. Vasileva, A.Y. Bandun, V.Y. Paina, Kinet. Katal. 35 (1994) 90-92.
[12] S. Stephens, M.J. Rossi, D.M. Golden, Int. J. Chem. Kinet. 18 (1986) 1133-1149.

[13] D. Helmig, Atmos. Environ. 31 (1997) 3635-3651.

[14] B. Dhandapani, S.T. Oyama, Appl. Catal. B Environ. 11 (1997) 129-166.

[15] D. Mehandjiev, A. Naidenov, Ozone Sci. Eng. 14 (1992) 277-282.

[16] I. Spasova, P. Nikolov, D. Mehandjiev, Ozone Sci. Eng. 29 (2007) 41-45.

[17] M. Muruganandham, J.J. Wu, Catal. Commun. 8 (2007) 668-672.

[18] Z.Z. Xu, Z.L. Chen, C. Joll, Y. Ben, J.M. Shen, H. Tao, Catal. Commun. 10 (2009) 1221-1225.

[19] H. Pan, L. Zhou, Y. Zhu, N. Peng, M. Gong, Y. Chen, Chin. J. Catal. 32 (2011) 1040-1045.

[20] M. Wang, P. Zhang, J. Li, C. Jiang, Chin. J. Catal. 35 (2014) 335-341.

[21] C. Jiang, P. Zhang, B. Zhang, J. Li, M. Wang, Ozone Sci. Eng. 35 (2013) 308-315.

[22] C. Subrahmanyam, D.A. Bulushev, L. Kiwi-Minsker, Appl. Catal. B Environ. 61 (2005) 98-106.

[23] T.L. Rakitskaya, A.Y. Bandurko, A.A. Ennan, V.Y. Paina, A.S. Rakitskiy, Microporous Mesoporous Mater. 43 (2001) 153-160.

[24] B. Zhang, P. Zhang, R. Shi, H. Wang, Chin. J. Catal. 30 (2009) 235-241.

[25] A. Naydenov, P. Konova, P. Nikolov, F. Klingstedt, N. Kumar, D. Kovacheva, P. Stefanov, R. Stoyanova, D. Mehandjiev, Catal. Today 137 (2008) 471-474.

[26] C. Ren, L. Zhou, H. Shang, Y. Chen, Chin. J. Catal. 35 (2014) 1-9.

[27] K.J. Chao, L.H. Lin, M.H. Yang, Catal. Lett. 38 (1996) 279-282.

[28] F. Kapteijn, A.D.V. Langeveld, J.A. Moulijn, M. Vandriel, A. Andreini, M.A. Vuurman, A.M. Turek, J.M. Jehng, I.E. Wachs, J. Catal. 150 (1994) 94-104.

[29] S. Baruah, J. Dutta, Sci. Technol. Adv. Mater. 10 (2009) 1-18.

[30] M.S. Whittingham, Curr. Opin. Solid State Mater. 1 (1996) 227-232.

[31] K. Namratha, K. Byrappa, Prog. Cryst. Growth Charact. 58 (2012) 14-42.

[32] H. Pérez, P. Navarro, J.J. Delgado, M. Montes, Appl. Catal. A Gen. 400 (2011) 238-248.

[33] I. Andjelkovic, D. Stankovic, J. Nesic, J. Krstic, P. Vulic, D. Manojlovic, G. Roglic, Ind Eng. Chem. Res. 53 (2014) 10841-10848.

[34] H. Yin, J. Xie, Q. Yang, C. Yin, Y. Wang, Y. Feng, Chem. Res. Appl. 15 (2003) 1-5.

[35] D. Mehandjiev, A. Naydenov, G. Ivanov, Appl. Catal. A Gen. 206 (2001) 13-18. 